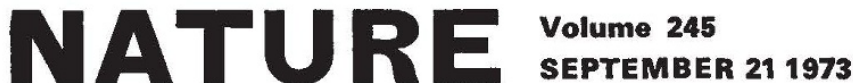

\section{No Tax onl Books and Papers}

IN April 1940 the Chancellor of the Exchequer announced the introduction of a purchase tax on certain goods. Among these were books. A campaign against this move was immediately started by publishers and a broader base of support rapidly developed. A deputation led by the Archbishop of Canterbury and including Sir Arthur Eddington and Professors A. V. Hill and R. H. Tawney tried to persuade the Chancellor to change his mind. When this failed, the Archbishop, Mr J. B. Priestley and Sir Geoffrey Faber pleaded with MPs for support. This was forthcoming, and in August 1940 the Chancellor announced the exemption of books from tax. The principle that books are not taxed has held since.

When Value Added Tax (VAT) replaced Purchase Tax and Selective Employment Tax in Britain, the principles were re-asserted. VAT (which, it has been said, should more correctly be called SPIT, for selling-price increase tax) is not levied on books, nor on newspapers and periodicals, nor (among other things) on food. The zerorating on printed matter is not part of a concession, say, to scientific and medical research (water is zero-rated, distilled water is not!) nor to the academic community; it is a clear affirmation of the importance attached to the printed word. Private Eye and Men Only are zero-rated alongside Nature and the Oxford English Dictionary.

A problem, however, is fast approaching, and was given wide publicity by $\mathrm{Mr}$ March Hunnings in the Times Literary Supplement of August 31. There will be strong pressure within months in the EEC for unified VAT rates. Other countries in the Common Market do not zero-rate books, so if unification is done on a majority basis Britain will be expected to raise the rate to at least $5 \%$. British diplomatic efforts are likely to be fully extended in attempting to keep food zero-rated.

The case for no taxation is as valid in 1973 as it was in 1940. Books and papers still live on the margins of most personal budgets - as desirable possessions but amongst the first to be jettisoned if money becomes tight. Furthermore, it will be the poorer, to whom the cost of books and papers represents a larger fraction of their income, who will suffer most. If the tax goes up on most consumer goods there is the possibility of a change in habits to settle for less. This is not easily done with printed matterthe choice is between buying and not buying.

The present zero-rating on printed matter is an assertion of the importance of thinking and participation. A clear line is drawn between, for instance, printed music (zerorated) and gramophone records (rated at 10\%); between books (zero-rated) and television sets (10\%). This is an enlightened attitude for a Government to take, especially as it is thereby denied of substantial revenue. It is, one hopes, not utterly starry-eyed to say that the absence of tax on printed matter ought to be maintained simply because it makes Britain a more civilized place.

What tactics should be adopted to attempt to retain things as they are?

Those in the publishing business can be accused of being motivated by self-interest; thus any organized opposition to such tax moves would have to be as broadly based as it was in 1940 to carry deep conviction, and it would have to be seen not to be a vehicle for another attack on Britain's membership of the EEC. Whereas representatives of trade unions, staunch defenders of the printed word, would provide eloquent support, their implacable stand on the EEC might prove an embarrassment. On the other hand, few distinguished scientists have revealed strong European prejudices. They would be admirable members of any opposition movement.

It should be said that such a movement would have to work within a European framework. There would undoubtedly be much sympathy in Whitehall for it, but the question is an international one and other countries within the EEC should be made aware of the depth of feeling. Two courses are possible. A case could be made that Britain should be allowed to continue as an exception in zero-rating. But a more imaginative approach would be to urge other countries to come into line with Britain (probably by exemption rather than zero-rating -an exquisite difference). There are reasons to believe the latter is the right way to go. It has less connotations of Britain as the loner and is thus not seen as a threat to EEC unity. Newspapers are already exempt in some countries. It could be a valuable boost to the as yet poorly developed concept of cultural benefits springing from European unity, by means of a levelling up rather than down of civilizing assets. It would be an excellent opportunity to make new contacts in Europe. And most obviously, it would, if successful, be good for everyone.

The question of VAT-rating is not a narrow domestic issue. If handled intelligently it could have broader European benefits. Moves towards VAT which President Nixon has made imply that now is also the time to raise the issue of exemption in the United States.

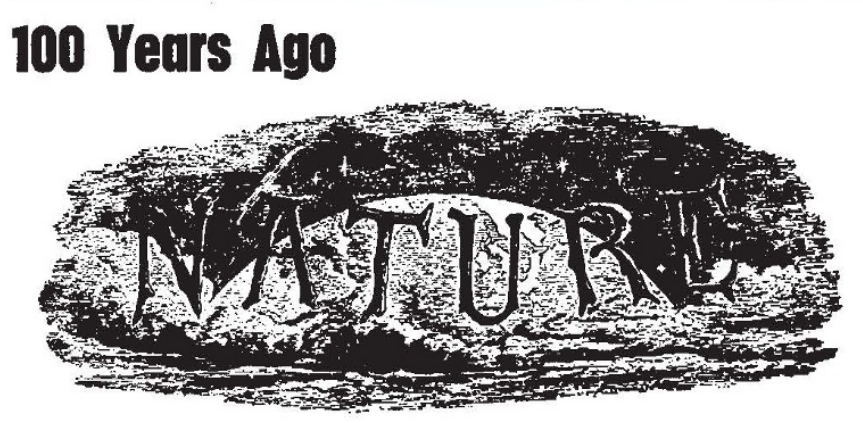

The soirée in St. George's Hall last Thursday was a great success ; indeed all the arrangements for the meeting have been satisfactory. The public lectures, by Profs. W. C. Williamson, Clerk-Maxwell, and Dr. Siemens were well attended, but the proportion of the working-classes present at the lecture on Fuel, which was specially intended for their benefit, was very small.

From the report on the British Association meeting at Bradford From Nature, 8, 448, September 25, 1873. 